\title{
PERBANDINGAN SIFAT KOLIGATIF CAMPURAN LARUTAN GARAM (NaCl, KCl, dan Na-Benzoat) DENGAN AIR ZAMZAM BERDASARKAN BERAT JENISNYA
}

\author{
SUSi RUSDIANI ${ }^{1}$, DEDE SUHENDAR ${ }^{1 *}$, DAN TETY SUdiARTI \\ ${ }^{1}$ Jurusan Kimia, Fakultas Sains dan Teknologi, UIN Sunan Gunung Djati Bandung, \\ Jl. A.H. Nasution No. 105, Bandung
}

*Email korespondensi: dede.suhendar@uinsgd.ac.id

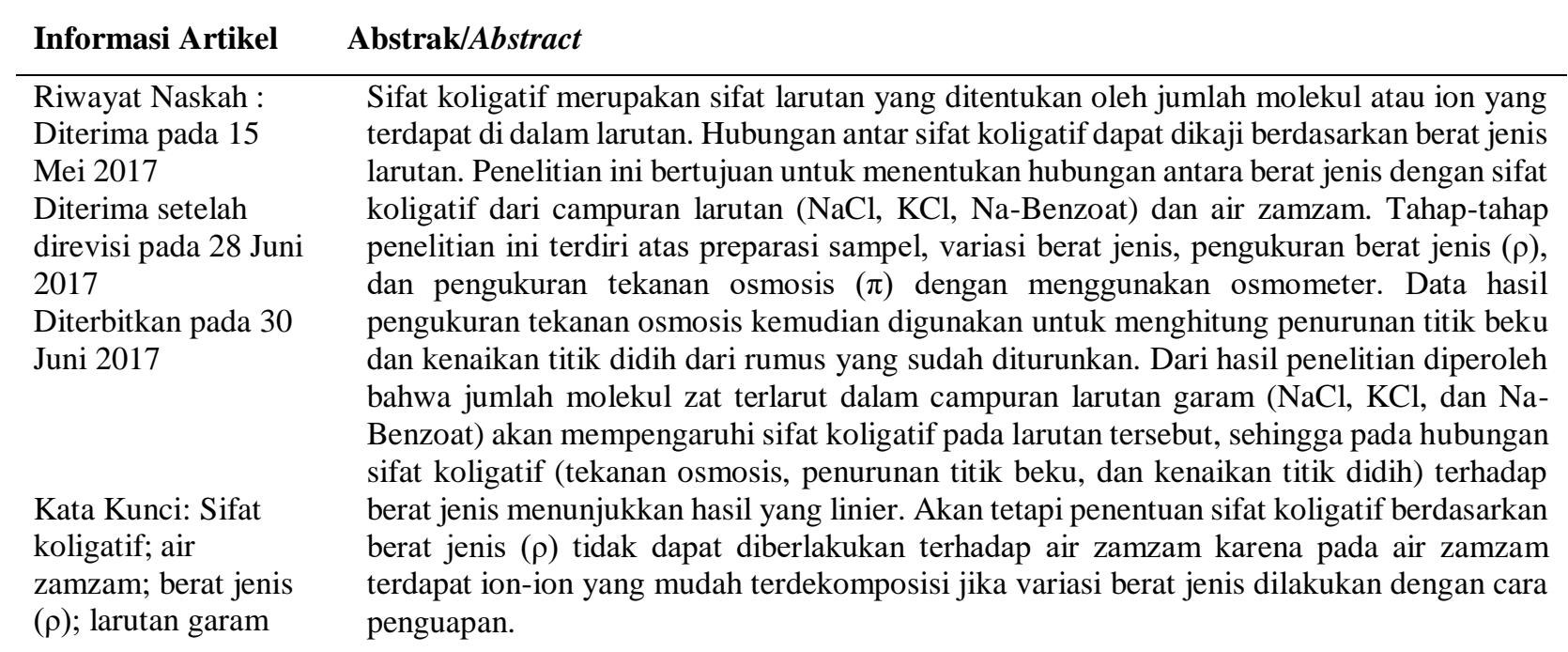

Keywords:

Colligative properties; zamzam water; density $(\rho)$; saline solution.

\begin{abstract}
The colligative properties of the solution properties are determined by the number of molecules or ions contained in the solution. Relations between colligative properties may be assessed, based on the density of the solution. This study aims to determine the relationship between the density of the colligative properties of a mixed solution ( $\mathrm{NaCl}$, $\mathrm{KCl}, \mathrm{Na}$ Benzoate) and zamzam water. The stages of this research consists of sample preparation, variation of density, specific gravity measurement $(\rho)$, and the measurement of the osmotic pressure ( $\pi$ ) by using osmometer. Osmotic pressure measurement is then used to calculate the freezing point depression and boiling point elevation of the formula that has been lowered. The result showed that the number of solute molecules in a mixture of saline solution ( $\mathrm{NaCl}, \mathrm{KCl}$, and $\mathrm{Na}$-Benzoate) will affect the colligative properties in the solution, so that the relationship colligative properties (osmotic pressure, freezing point depression and boiling point elevation) to density showed linear results. But the determination of colligative properties based on the density $(\rho)$ can't be enforced against zamzam water because there zamzam water ions easily decomposed if the variation of density is done by evaporation.
\end{abstract}

\section{PENDAHULAN}

Sifat koligatif adalah sifat larutan yang tidak bergantung pada jenis zat terlarut tetapi bergantung pada banyaknya partikel zat terlarut dalam larutan [1]. Sifat koligatif larutan terdiri atas dua jenis, yaitu sifat koligatif larutan elektrolit dan sifat koligatif larutan non elektrolit. Hal itu disebabkan zat terlarut dalam larutan elektrolit bertambah jumlahnya karena terurai menjadi ion-ion sesuai dengan hal-hal tersebut. Sifat koligatif larutan nonelektrolit lebih rendah dari pada sifat koligatif larutan elektrolit.

Larutan murni (air) memiliki sifat titik beku, titik didih, dan tekanan uap. Bila zat non elektrolit seperti gula, urea, dan gliserol dimasukkan ke dalam pelarut murni, maka akan mengubah sifatsifat larutan tersebut. Perubahan tersebut meliputi penurunan titik beku, kenaikan titik didih, penurunan tekanan uap, dan menimbulkan tekanan osmosis.

Apabila suatu senyawa non-elektrolit terlarut di dalam pelarut, sifat-sifat pelarut murni berubah dengan adanya zat terlarut. Sifat-sifat fisika seperti titik didih, titik beku, tekanan uap berbeda dengan pelarut murni. Adanya perubahan ini bergantung pada jumlah partikel-partikel pelarut yang terdapat di dalam larutan.

Jumlah partikel terlarut sebenarnya sebanding dengan berat jenis larutannya, maka 
akan terdapat hubungan, jika berat jenis bertambah maka akan menurunkan titik beku dan kenaikan titik didih dari pelarut murninya [2].

Dalam ilmu kimia perlu diketahui tentang sifat-sifat suatu larutan. Pengetahuan ini sangat penting mengingat sebagian besar reaksi yang terjadi dalam bentuk larutan dengan pelarut air. Oleh pengetahuan mengenai sifat koligatif larutan sangat diperlukan. Selama ini kita ketahui dalam sifat koligatif larutan khususnya pada penurunan titik beku dan kenaikan titik didih harus dihitung dan ditentukan dari molalitasnya melalui tahapan yang cukup panjang. Dari penelusuran ini, sifat koligatif larutan akan ditentukan dengan hanya mengukur berat jenis dari larutan saja, dapat ditemukan rumus penurunan titik beku dan kenaikan titik didihnya dengan menurunkan beberapa rumus, dan disinkronisasikan berdasarkan data hasil pengukuran dari osmometer yaitu tekanan osmosis.

Dari penelitian sebelumnya telah dilakukan studi pendahuluan sifat koligatif berdasarkan eksperimen dari larutan kalium klorida dan air kelapa ditinjau dari dari penurunan titik bekunya. Hasil dari penelitian tersebut menunjukkan perbandingan pengaruh variasi konsentrasi antara larutan $\mathrm{KCl}$ dengan kepekatan air kelapa terhadap penurunan titik beku dapat ditentukan dengan kecenderungan kurva pada grafiknya dimana semakin pekat konsentrasinya maka penurunan titik bekunya akan semakin konstan. Hubungan antara berat jenis dengan penurunan titik beku ditunjukkan dengan kesebandingan antara nilai berat jenis dengan titik beku dilihat dari kemiripan bentuk kurva dari larutan $\mathrm{KCl}$ dan air kelapa. Pada penelitian tersebut digunakan $\mathrm{KCl}$ grade teknis tetapi tetap efektif untuk digunakan dan tidak mempengaruhi analisis sifat koligatif [3].

Berdasarkan hasil penelitian yang telah dilakukan, pengukuran kalibrasi sebaiknya menggunakan termometer digital yang memiliki akurasi dan presisi yang lebih baik. Juga perlu penyidikan lebih lanjut untuk menguji keberlakuan hubungan berat jenis menggunakan instrumen yang lebih layak dengan menggunakan osmometer [2]. Oleh karena itu, untuk menindaklanjuti penelitian sifat koligatif ini akan dilakukan pada larutan Natrium Klorida, Kalium Klorida, Natrium Benzoat, campuran larutan dari ketiga zat terlarut tersebut, dan air zamzam. Dilakukan juga pada air zamzam yaitu sebagai pembanding, karena air zamzam merupakan suatu larutan yang tidak diketahui konsentrasi dan zat-zat terlarutnya. Metode yang digunakan yaitu dengan pengukuran tekanan osmosis dengan osmometer. Dengan mendapatkan nilai tekanan osmosis, secara tidak langsung dapat menentukan penurunan titik beku dan kenaikan titik didih dengan menurunkan beberapa rumus, sehingga metode ini dapat digunakan untuk menentukan sifat koligatif dengan akurasi dan presisi yang lebih baik.

\section{EKSPERIMEN}

\section{Material}

Bahan-bahan yang akan digunakan dalam penelitian ini adalah $\mathrm{NaCl}$ grade Pro Analisis, $\mathrm{KCl}$ grade Pro Analisis, Natrium Benzoat grade Pro Analisis, dan Air zamzam.

\section{Instrumentasi}

Instrumentasi yang digunakan adalah osmometer model 3250.

\section{Prosedur Kerja}

Pada penelitian ini metodologi penelitian yang digunakan meliputi preparasi sampel, pengukuran berat jenis $(\rho)$, dan pengukuran tekanan osmosis $(\pi)$. Data hasil pengamatan ini selanjutnya akan digunakan untuk menganalisis hubungan berat jenis dengan sifat koligatif larutan. Larutan yang dianalisis adalah larutan $\mathrm{NaCl}, \mathrm{KCl}$, Na-Benzoat dalam beberapa konsentrasi, Campuran larutan garam ( $\mathrm{NaCl}, \mathrm{KCl}, \mathrm{Na}-\mathrm{Benzoat})$ dan Air zamzam.

\section{Preparasi Larutan Garam}

Dalam tahap preparasi larutan garam, garam yang digunakan adalah $\mathrm{NaCl}, \mathrm{KCl}$, dan $\mathrm{Na}-$ benzoat. Garam-garam tersebut ditimbang sesuai dengan variasi konsentrasi pada konsentrasi 0,0, $0,2,0,4,0,6,0,8$, dan $1 \mathrm{M}$. Kemudian masingmasing garam dilarutkan dengan akua DM sebanyak $50 \mathrm{~mL}$.

\section{Preparasi Air Zamzam}

Air zamzam yang digunakan didapat pada saat musim haji bulan oktober tahun 2014, yang mana air zamzam tersebut diambil dari sumber mata air zamzam oleh petugas haji. Untuk mendapatkan variasi konsentrasi dari air zamzam digunakan metode penguapan dengan cara destilasi dan dengan metode pengenceran. Pada metode penguapan, air zamzam yang digunakan sebanyak $500 \mathrm{~mL}$ dan di uapkan secara bertahap dengan cara destilasi. Setelah suhu penguapan mencapai $100^{\circ} \mathrm{C}$, kemudian secara bertahap sampel air zamzam diambil sebanyak $40 \mathrm{~mL}$ pada waktu 30, 60, dan 90 menit. Pada metode pengenceran, air zamzam 
diencerkan $10 \%$ dan $20 \%$ dari berat air zamzam. Masing-masing sampel dilakukan pengukuran berat jenis air zamzam setelah proses penguapan, kemudian diukur tekanan osmosisnya dengan menggunakan osmometer.

Preparasi Campuran Larutan Garam ( $\mathrm{NaCl}, \mathrm{KCl}$, dan Na-Benzoat)

Dalam tahap preparasi campuran $\mathrm{NaCl}, \mathrm{KCl}$, dan Na-benzoat, garam-garam tersebut ditimbang sesuai dengan variasi campuran yaitu 1:1:1 dan $1: 1: 1,3$. Kemudian masing-masing campuran dibuat variasi konsentrasi dari konsentrasi encer sampai konsentrasi pekat yang disajikan pada Tabel 1. Kemudian masing-masing garam dilarutkan dengan akuades sebanyak $50 \mathrm{~mL}$.

Tabel 1. Variasi Konsentrasi Campuran Larutan Garam

\begin{tabular}{cc}
\hline \multicolumn{2}{c}{ Konsentrasi (M) } \\
\hline Campuran 1:1:1 & Campuran 1:1:1,3 \\
0,0 & 0,0 \\
0,2 & 0,1 \\
0,4 & 0,2 \\
0,6 & 0,3 \\
0,8 & 0,4 \\
1,0 & 0,5 \\
\hline
\end{tabular}

Pengukuran Berat Jenis ( $\rho$ )

Untuk pengukuran berat jenis digunakan piknometer $25 \mathrm{~mL}$. Pengukuran berat jenis ini dilakukan pada masing-masing larutan dengan variasi konsentrasi. Pada air zamzam pengukuran berat jenis dilakukan setelah proses pemanasan dan pengenceran.

\section{Pengukuran Tekanan Osmosis ( $\pi$ )}

Untuk pengukuran tekanan osmosis pada larutan $\mathrm{NaCl}, \mathrm{KCl}, \mathrm{Na}$-Benzoat, dan Air zamzam, masing-masing variasi konsentrasi dimasukkan ke dalam vial. Kemudian masing-masing larutan tersebut diukur menggunakan osmometer untuk mendapatkan nilai tekanan osmosis.

\section{HASIL DAN PEMBAHASAN}

\section{Analisis Berat Jenis}

Proses pengukuran berat jenis dilakukan pada masing-masing variasi larutan $\mathrm{NaCl}, \mathrm{KCl}, \mathrm{Na}-$ Benzoat dan Air Zamzam. Larutan-larutan tersebut dibuat dengan berbagai variasi konsentrasi yakni 0,0-1 M. Rentang konsentrasi ini dibuat berdasarkan pertimbangan bahwa osmometer tidak dapat membaca hasil analisis pada konsentrasi yang tinggi.

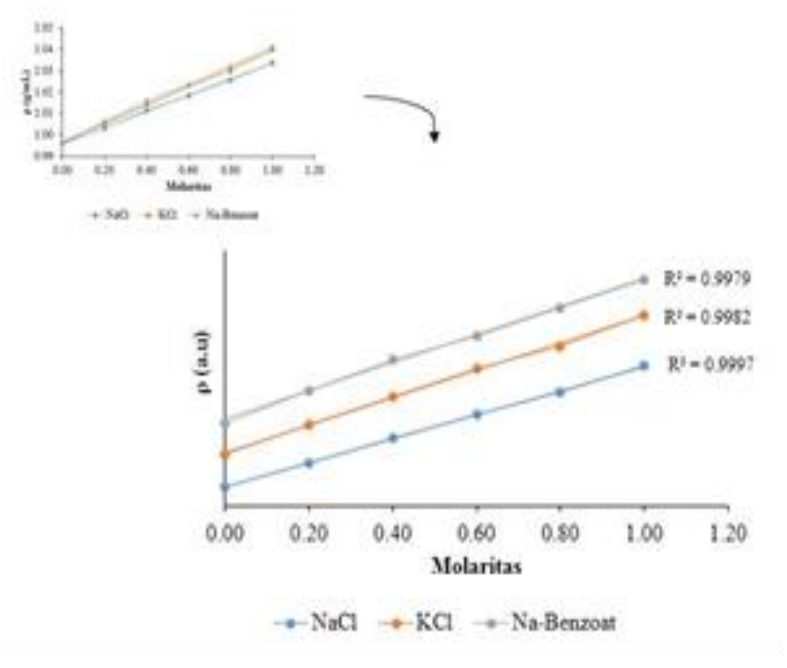

Gambar 1. Hubungan berat jenis terhadap konsentrasi untuk larutan $\mathrm{NaCl}, \mathrm{KCl}$ dan $\mathrm{Na}-\mathrm{Benzoat}$

Data berat jenis larutan ini sebanding dengan banyaknya partikel dalam volume larutannya. Dengan demikian hubungan antara konsentrasi dengan berat jenis adalah berbanding lurus, dimana makin tinggi konsentrasi maka makin tinggi pula berat jenisnya. Hal ini ditunjukkan pada Gambar 1.

Penentuan variasi konsentrasi sampel air zamzam dilakukan dengan proses pengenceran dan pemanasan. Sampel pertama dan kedua merupakan air zamzam dengan pengenceran $10 \%$ dan $20 \%$ dari berat air zamzam. Sampel ketiga merupakan air zamzam yang tidak mendapatkan perlakuan pengenceran maupun pemanasan atau air zamzam $100 \%$. Sedangkan sampel selanjutnya dilakukan pemanasan dalam berbagai variasi lama waktu pemanasan, dengan menggunakan volume awalnya sebanyak $500 \mathrm{~mL}$ air zamzam. Variasi sampel air zamzam dibuat dalam enam variasi yang selanjutnya dilakukan analisis berat jenis pada masing-masing sampel air zamzam.

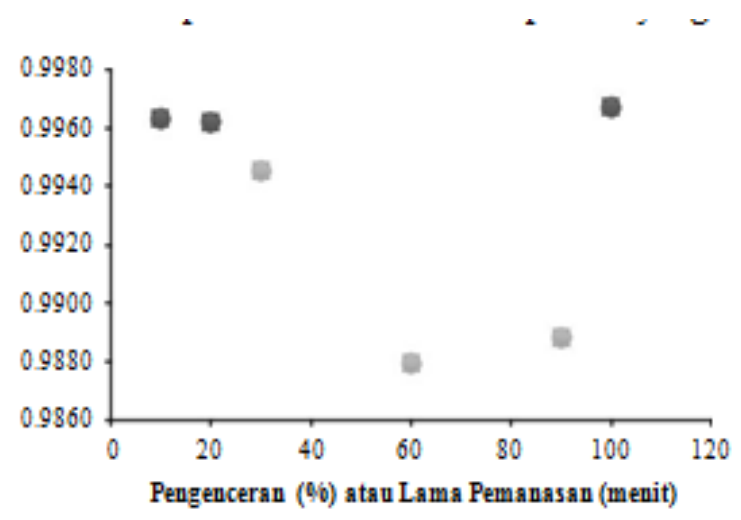

Gambar 2. Hubungan Berat Jenis Terhadap Pengenceran atau Lama Pemanasan Air Zamzam 
Penggunaan air zamzam dalam penentuan sifat koligatif bertujuan untuk menguji keberlakuan sifat koligatif pada larutan yang tidak diketahui zatzat terlarutnya. Pada pengukuran berat jenis air zamzam dengan proses pengenceran dan pemanasan yang ditunjukkan oleh Gambar 2 tidak menunjukkan hasil yang linier, hal ini dikarenakan pada air zamzam terdapat zat yang mudah terdekomposisi ketika dipanaskan.

Berat jenis rata-rata air zamzam adalah $0,9965 \mathrm{~g} / \mathrm{mL}$ yang diukur pada suhu $27^{\circ} \mathrm{C}$ [4]. Berat jenis dipengaruhi oleh suhu dan tekanan dan tidak dipengaruhi dari jenis atau sumber air tersebut. Pada air zamzam menunjukkan kadar bikarbonat yang lebih tinggi dari pada air kemasan yaitu 103 $\mathrm{mg} / \mathrm{L}$ [4]. Kadar bikarbonat yang tinggi pada air zamzam berasal dari hasil pelapukan batu kapur dan dolomit yang bereaksi dengan $\mathrm{CO}_{2}$. Batu kapur dan dolomit memiliki daya larut rendah, namun dengan keberadaan $\mathrm{CO}_{2}$ kelarutan senyawasenyawa tersebut meninggkat [5].

Jika dipanaskan, kebanyakan karbonat cenderung mengalami dekomposisi membentuk oksida logam dan karbodioksida. Ion karbonat kurang stabil terhadap pemanasan, karena karbonat mulai kehilangan karbondioksida dan air pada suhu $100^{\circ} \mathrm{C}$. Sedangkan pada percobaan, lama pemanasan dimulai setelah suhu mencapai $100^{\circ} \mathrm{C}$, sehingga ketika dipanaskan tidak terjadi pemekatan namun terjadi hilangnya kandungan ion-ion (karbonat/bikarbonat) yang cukup signifikan. Karena banyak ion yang hilang artinya akan terjadi penurunan berat jenis. Pengeluaran air dari air zamzam diikuti hilangnya ion karbonat atau bikarbonat. Jadi pada air zamzam, ketika dipanaskan tidak terjadi pemekatan karena hilangnya ion-ion di dalam air zamzam tersebut. Dalam hal ini artinya air zamzam dengan proses pemanasan tidak berlaku pada sifat koligatif dengan diukur berat jenisnya saja.

Pembuktian keberlakuan sifat koligatif pada air zamzam dilakukan percobaan campuran larutan garam $(\mathrm{NaCl}, \mathrm{KCl}$, dan Na-Benzoat) 1:1:1 dan 1:1:1,3, yang mana pada campuran 1:1:1 terdiri atas $0,165 \mathrm{~mol} \mathrm{NaCl}: 0,165 \mathrm{~mol} \mathrm{KCl}: 0,165 \mathrm{~mol}$ Na-Benzoat untuk konsentrasi $1 \mathrm{M}$, dan pada campuran $1: 1: 1,3$ terdiri atas $0,075 \mathrm{~mol} \mathrm{NaCl}$ : $0,075 \mathrm{~mol} \mathrm{KCl}: 0,10 \mathrm{~mol}$ Na-Benzoat untuk konsentrasi 0,5 M. Karena air zamzam merupakan suatu campuran yang terdiri atas beberapa zat terlarut, maka dilakukan juga percobaan terhadap campuran tiga zat terlarut. Analisis berat jenis campuran larutan garam menunjukkan hasil yang linier, berat jenis makin besar ketika konsentrasi larutan makin besar pula, artinya makin banyak zat terlarut yang terdapat di dalam larutan. Hal ini terjadi karena pada campuran tersebut tidak mengandung ion-ion yang mudah terdekomposisi. Hubungan berat jenis terhadap konsentrasi campuran larutan garam disajikan pada Gambar 3.

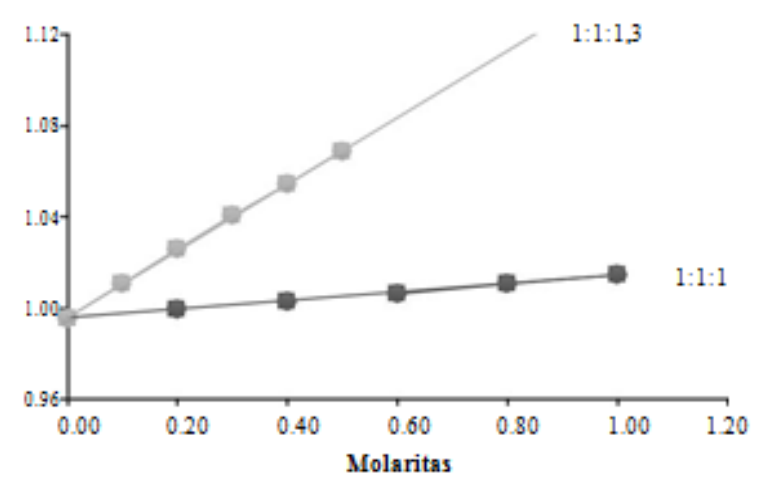

Gambar 3. Hubungan Berat Jenis Terhadap Konsentrasi Campuran Larutan Garam ( $\mathrm{NaCl}, \mathrm{KCl}$, dan Na-Benzoat)

\section{Analisis Tekanan Osmosis}

Analisis tekanan osmosis dilakukan dengan menggunakan instrumen osmometer. Masingmasing sampel di ukur sesuai variasi konsentrasi dari larutan tersebut. Variasi konsentrasi masingmasing larutan dibuat berdasarkan kemampuan terdeteksinya pada osmometer. Osmometer yang digunakan merupakan osmometer model 3250 yang pada kondisi low hanya dapat mendeteksi hingga $3000 \mathrm{mOsm}$ atau pada kisaran 67,2 atm, dan pada kondisi high mampu mendeteksi hingga 4000 mOsm atau 89,6 atm. Maka dari itu osmometer hanya dapat mengukur larutan yang encer, karena osmometer ini dipergunakan untuk mengukur tekanan osmosis pada obat steril yang kadarnya rendah.

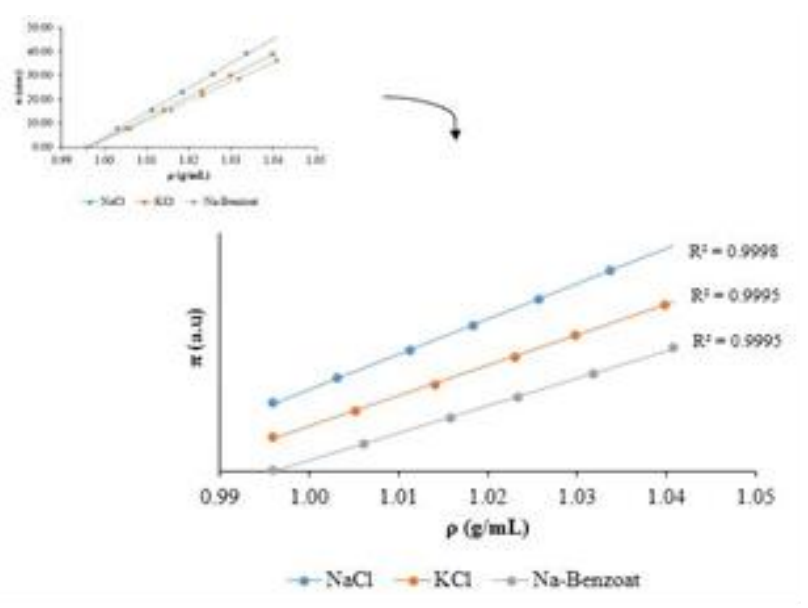

Gambar 4. Hubungan Tekanan Osmosis Terhadap Berat Jenis $\mathrm{NaCl}, \mathrm{KCl}$ dan Na-Benzoat

Pada Gambar 4 menunjukkan bahwa makin tinggi berat jenis maka makin tinggi pula tekanan osmosisnya, karena konsentrasi sebandi. Dalam hal ini, artinya pada larutan garam konsentrasi akan 
berbanding lurus dengan berat jenis, dan akan berbanding lurus pula dengan tekanan osmosis. Persamaan garis untuk $\mathrm{NaCl}$ yaitu $\mathrm{y}=1036,2 \mathrm{x}-$ 1032,1 dengan regresi 0,9998 , untuk $\mathrm{KCl}$ yaitu $\mathrm{y}=$ 894,19x - 890,98 dengan regresi 0,9995, dan pada Na-Benzoat yaitu $\mathrm{y}=813,22 \mathrm{x}-810,37$ dengan regresi 0,9995. Pada persamaan garis tersebut menunjukkan korelasi antara berat jenis dan tekanan osmosis yang dibuat secara regresi linier untuk mendapatkan konstanta-konstanta yang berlaku untuk setiap larutan.

Jika pada air zamzam hubungan berat jenis terhadap lama pemasanasan tidak berbanding lurus, berbeda halnya dengan hubungan tekanan osmosis air zamzam terhadap pengenceran atau lama pemanasan seperti yang ditunjukkan pada Gambar 5. Pada hasil tersebut menunjukkan bahwa pengenceran atau lama pemanasan pada air zamzam berbanding lurus tekanan osmosisnya.

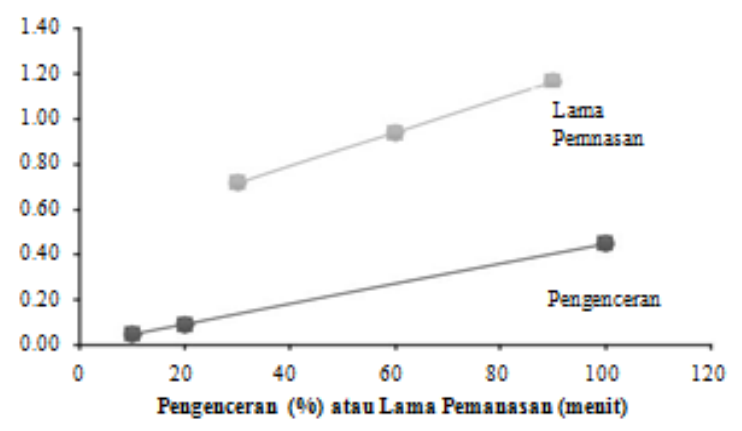

Gambar 5. Hubungan Tekanan Osmosis (atm) Terhadap Pengenceran atau Lama Pemanasan

Berbeda halnya dengan hubungan tekanan osmosis terhadap berat jenis air zamzam yang ditunjukkan pada Gambar 6, dari hasil tersebut menunjukkan bahwa tekanan osmosis pada air zamzam tidak berbanding lurus dengan berat jenis air zamzam. Seperti yang sudah dijelaskan sebelumnya bahwa pada air zamzam ketika dipanaskan akan kehilangan beberapa ion, maka dari itu pemekatan air zamzam tidak dapat dilakukan dengan pemanasan karena pada air zamzam terdapat ion-ion yang mudah terdekomposisi.

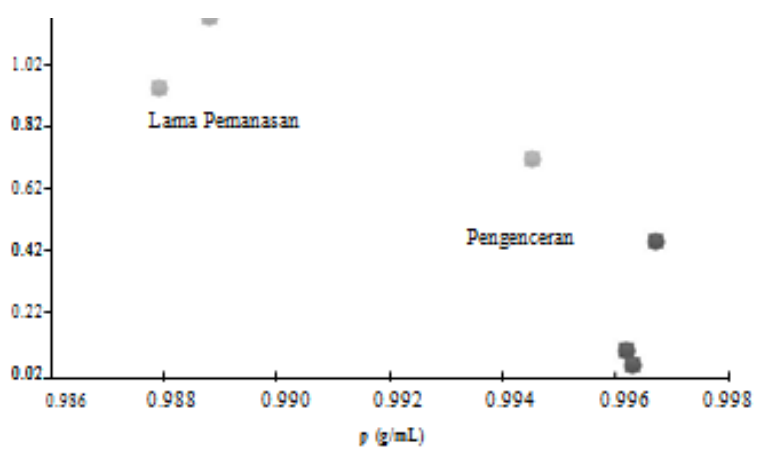

Gambar 6. Hubungan Tekanan Osmosis (atm) Terhadap Berat Jenis Air Zamzam
Selanjutnya analisis tekanan osmosis pada campuran larutan garam, sama hal nya seperti pada pengukuran berat jenis, analisis tekanan osmosis pada campuran larutan garam dibuat dalam variasi konsentrasi yang sama. Dari data tersebut di dapat hasil yang linier, yaitu makin tinggi konsentrasi pada campuran maka makin tinggi pula tekanan osmosisnya. Karena pada campuran ini sudah diketahui komposisi masing-masing zat terlarutnya. Hasil tersebut ditunjukkan pada Gambar 7.

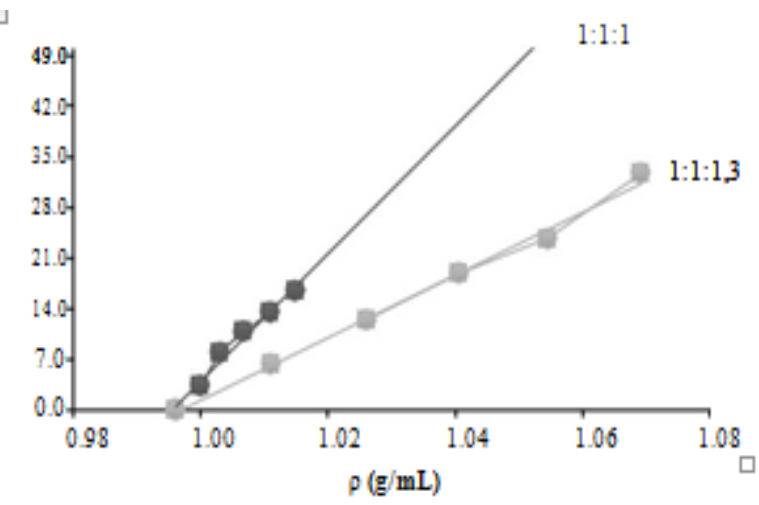

Gambar 7. Hubungan Tekanan Osmosis (atm) Terhadap Berat Jenis Campuran Larutan Garam ( $\mathrm{NaCl}$, $\mathrm{KCl}$, dan Natrium Benzoat)

Pada variasi campuran larutan garam tersebut menunjukkan hasil yang tidak terlalu linier yang ditunjukkan oleh nilai regresi linier untuk variasi 1:1:1 yaitu 0,9831 dan variasi $1: 1: 1,3$ yaitu 0,9943 . Hal ini disebabkan karena molekulmolekul saling terikat akibat adanya tarik-menarik antar molekul [1]. Bila suatu zat (zat terlarut) larut dalam zat lainnya (pelarut), partikel zat terlarut akan menyebar keseluruh pelarut yang mengakibatkan adanya interaksi pelarut-zat terlarut. Akibat adanya interksi ini, maka terjadi proses pelarutan yang mana proses pelarutan ini dipengaruhi oleh dua faktor. Faktor pertama adalah energy, yang menentukan apakah proses pelarutan bersifat eksotermik atau endotermik. Faktor kedua ialah kecenderungan hakiki menuju ketidakteraturan [1]. Maka dari itu, pada campuran larutan garam tersebut, ketika molekul zat terlarut dan molekul pelarut bercampur membentuk larutan, ketidakteraturan akan meningkat. Karena dalam keadaan murni, pelarut dan zat terlarut memiliki derajat keteraturan yang cukup tinggi, tampak dari cukup teraturnya susunan atom, molekul, atau ion dalam ruang tiga dimensi [1]. Keteraturan yang tinggi ini akan hancur bila zat terlarut larut dalam pelarut. Jadi, proses pelarutan diiringi oleh peningkatan ketidak teraturan atau keacakan. 


\section{Analisis Penurunan Titik Beku}

Penurunan titik beku dapat di analisis dengan melihat data tekanan osmosis. Karena hubungan penurunan titik beku terhadap berat jenis, dapat diturunkan dari hubungan penurunan titik beku terhadap tekanan osmosis dengan nilai mol yang sama pada kedua persamaan rumus [2]. Pada sifat koligatif, penurunan titik beku dihitung menggunakan persamaan:

$$
\begin{aligned}
& \Delta T_{f}=K_{f} \frac{\text { mol }_{\text {berat }}}{\text { pelarut }} x i \\
& \text { mol }=\frac{\Delta T_{f} x \text { Berat }_{\text {pelarut }}}{K_{f} x i}
\end{aligned}
$$

Sedangkan tekanan osmosis dihitung dengan menggunakan persamaan:

$$
\begin{gathered}
\pi=\frac{\text { mol }}{V_{\text {larutan }}} \times R \times T \times i \\
\text { mol }=\frac{V_{\text {larutan }} \times \pi}{R \times T \times i}
\end{gathered}
$$

Karena pada kedua persamaan terdapat variabel yang sama (mol) maka didapatkan hubungan dari persamaan $\Delta \mathrm{Tf}$ dengan $\pi$ :

$$
\begin{aligned}
{\text { mol } \Delta T_{f}}_{f} & =\text { mol } \pi \\
\frac{\Delta T_{f} \times \text { berat }_{\text {pelarut }}}{K_{f} \times i} & =\frac{V_{\text {larutan }} \times \pi}{R \times T \times i} \\
\frac{\Delta T_{f} \times \text { berat }_{\text {pelarut }}}{K_{f} \times \dot{t}} & =\frac{V_{\text {larutan }} \times \pi}{R \times T \times \dot{t}} \\
\pi & =\frac{R \times T}{K_{f}} \times \frac{\Delta T_{f} \times \text { Berat }_{\text {pelarut }}}{V_{\text {larutan }}}
\end{aligned}
$$

Karena air memiliki berat jenis $1 \mathrm{Kg} / \mathrm{L}$, maka dapat diasumsikan bahwa $\mathrm{Kg}$ pelarut $=\mathrm{L}$ larutan, maka persamaan menjadi:

$$
\begin{aligned}
& \pi=\frac{R x T}{K_{f}} x \frac{V_{\text {pelarut }}}{V_{\text {larutan }}} x \Delta T_{f} \\
& \pi=\frac{R x T}{K_{f}} x \% V_{\text {pelarut }} x \Delta T_{f}
\end{aligned}
$$

Bila komposisi volume air tidak diketahui atau sulit ditentukan, maka dapat digunakan data berat jenis, sehingga persamaan menjadi:

$$
\pi=\frac{R \times T}{K_{f}} \times \frac{\text { Berat }_{\text {pelarut }} / \rho_{\text {pelarut }}}{\text { Berat }_{\text {larutan }} / \rho_{\text {larutan }}} \times \Delta T_{f}
$$

$$
\pi=\frac{R \times T}{K_{f}} \times \frac{\text { Berat }_{\text {pelarut }}}{\text { Berat }_{\text {larutan }}} \times \frac{\rho_{\text {larutan }}}{\rho_{\text {pelarut }}} \times \Delta T_{f}
$$

Dari rumus diatas dapat diketahui hasil penurunan titik beku dari masing-masing larutan. Hubungan penurunan titik beku terhadap berat jenis untuk larutan $\mathrm{NaCl}, \mathrm{KCl}$, dan Na-Benzoat disajikan pada Gambar 8.

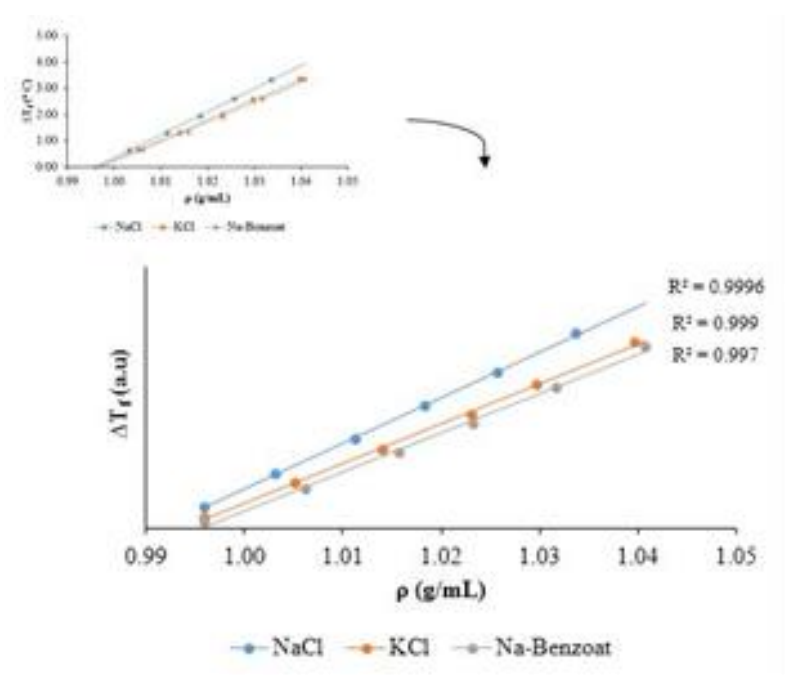

Gambar 8. Hubungan Penurunan Titik Beku Terhadap Berat Jenis $\mathrm{NaCl}, \mathrm{KCl}$, dan Na-Benzoat

Berdasarkan Gambar 8 menunjukkan bahwa makin besar penurunan titik beku maka makin besar pula berat jenisnya. Hal tersebut sesuai dengan sifat koligatif larutan yang menyatakan bahwa jumlah zat terlarut dalam larutan mempengaruhi penurunan titik beku, jadi makin banyak jumlah zat terlarut maka titik beku dari larutan tersebut makin rendah. Sama halnya pada tekanan osmosis, karena pada tekanan osmosis berbanding lurus dengan berat jenis, maka penurunan titik beku akan berbanding lurus pula dengan berat jenis. Persamaan garis untuk $\mathrm{NaCl}$ yaitu $\mathrm{y}=87,788 \mathrm{x}-87,451$ dengan regresi 0,9996 , persamaan garis untuk $\mathrm{KCl}$ yaitu $\mathrm{y}=76,546 \mathrm{x}$ 76,285 dengan regresi 0,999 , dan untuk $\mathrm{Na}-$ Benzoat persamaan garisnya yaitu $\mathrm{y}=74,872 \mathrm{x}$ 74,657 dengan regresi 0,997.

Analisis penurunan titik beku untuk campuran larutan garam $(\mathrm{NaCl}, \mathrm{KCl}$, dan $\mathrm{Na}-$ Benzoat) dihitung menggunakan rumus yang sama seperti yang sudah dijelaskan sebelumnya. Hubungan penurunan titik beku terhadap berat jenis campuran disajikan pada Gambar 9. Dari gambar tersebut menunjukkan bahwa penurunan titik beku berbanding lurus dengan berat jenis, karena berdasarkan rumus yang digunakan tekanan osmosis akan berbanding lurus dengan penurunan titik beku. 


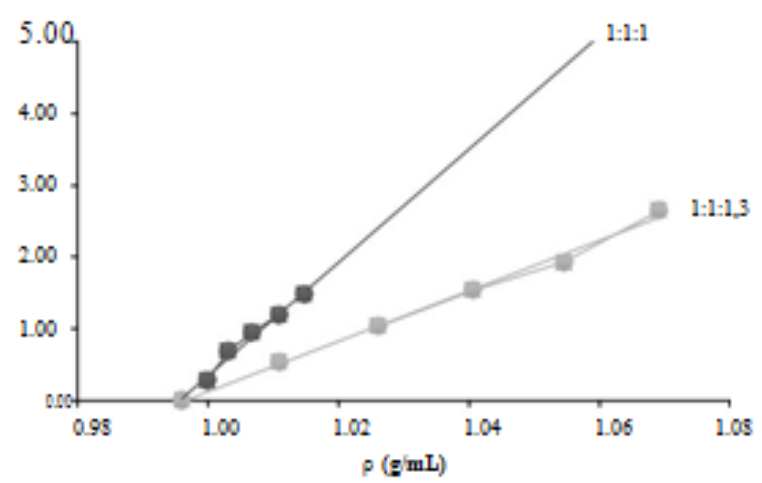

Gambar 9. Hubungan Penurunan Titik Beku Terhadap Berat Jenis Campuran Larutan Garam $(\mathrm{NaCl}, \mathrm{KCl}$, dan Na-Benzoat).

Pengaruh kehadiran zat terlarut yang terdisosiasi di dalam pelarut menghasilkan ion-ion yang berakibat pada beragamnya bentuk molekul, sehingga membutuhkan suhu yang lebih rendah untuk mencapai keteraturan larutan. Oleh karena itu, larutan memiliki titik beku lebih rendah dari pelarutnya.

Penurunan titik beku ini melibatkan transisi dari keadaan tidak teratur ke keadaan teratur. Pada hubungan penurunan titik beku terhadap berat jenis menunjukkan hasil yang tidak terlalu linier seperti halnya pada tekanan osmosis. Karena suatu larutan lebih tidak teratur dibandingkan pelarut, maka lebih banyak energy yang harus diambil untuk meciptakan keteraturan dibandingkan pelarut murni. Maka dari itu, larutan memiliki titik beku lebih rendah dibandingkan pelarut [1].

\section{Analisis Kenaikan Titik Didih}

Analisis kenaikan titik didih dapat juga dihitung dari data tekanan osmosis. Perhitungan yang dilakukan adalah dengan menggunakan rumus yang sama pada penurunan titik beku, akan tetapi $\Delta \mathrm{Tf}$ diganti dengan $\Delta \mathrm{Tb}$. Karena tekanan osmosis akan berbanding lurus dengan penurunan titik beku dan kenaikan titik didih. Maka rumus yang digunakan adalah:

$$
\pi=\frac{R \times T}{K_{b}} \times \frac{\text { Berat }_{\text {pelarut }}}{\text { Berat }_{\text {larutan }}} \times \frac{\rho_{\text {larutan }}}{\rho_{\text {pelarut }}} \times \Delta T_{b}
$$

Berdasarkan rumus tersebut didapat data hubungan kenaikan titik didih terhadap berat jenisnya disajikan pada Gambar 10. Dari gambar tersebut didapat persamaan garis untuk $\mathrm{NaCl}$ yaitu $\mathrm{y}=24,629 \mathrm{x}-24,535$ dengan regresi 0,9997, persamaan garis untuk $\mathrm{KCl}$ yaitu $\mathrm{y}=21,401 \mathrm{x}$ 21,328 dengan regresi 0,999 , dan untuk $\mathrm{Na}-$ Benzoat persamaan garisnya yaitu $\mathrm{y}=20,934 \mathrm{x}-$ 20,874 dengan regresi 0,9969 .

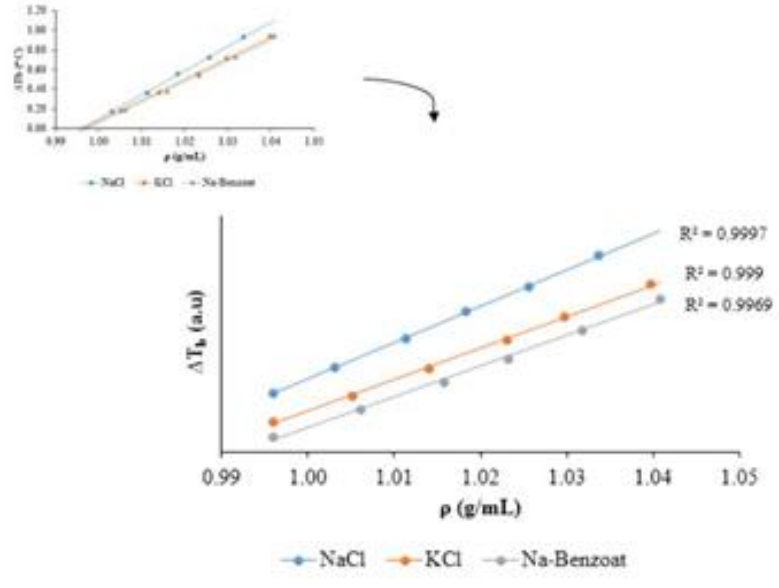

Gambar 10. Hubungan Kenaikan Titik Didih Terhadap Berat Jenis (a) $\mathrm{NaCl}$ (b) $\mathrm{KCl}$ (c) Na-Benzoat

Pada Gambar 10 menunjukkan bahwa kenaikan titik didih meningkat seiring dengan meningkatnya berat jenis. Hal ini terjadi karena titik didih suatu larutan lebih tinggi atau lebih rendah dari pada titik didih pelarut, bergantung pada kemudahan zat terlarut itu menguap dibandingkan dengan pelarutnya [1]. Jika suatu zat terlarut tidak mudah menguap, maka larutan akan mendidih pada suhu yang lebih tinggi dari pada titik didih pelarutnya. Sebaliknya, jika zat terlarutnya mudah menguap, maka larutan akan mendidih pada suhu dibawah titik didih pelarutnya.

Selanjutnya, penentuan kenaikan titik didih juga dilakukan pada campuran larutan garam $(\mathrm{NaCl}, \mathrm{KCl}, \quad$ dan Na-Benzoat) dengan menggunakan rumus yang sama seperti pada larutan tunggal. Pada campuran larutan garam menunjukkan hasil yang linier seperti pada penurunan titik beku, karena zat terlarut pada campuran tersebut sudah diketahui dan dapat dihitung jumlah dari masing-masing zat terlarutnya. Hubungan kenaikan titik didih dengan berat jenisnya disajikan pada Gambar 11.

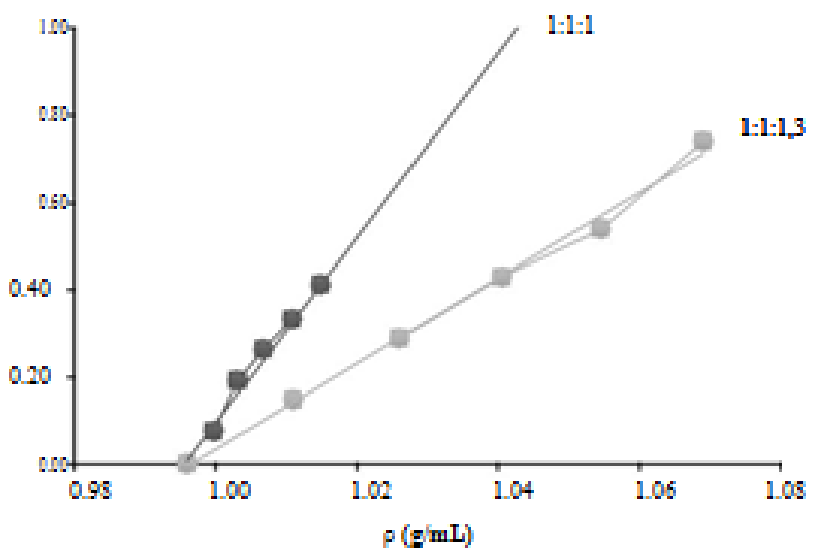

Gambar 11. Hubungan Kenaikan Titik Didih Terhadap Berat Jenis Campuran Larutan Garam ( $\mathrm{NaCl}, \mathrm{KCl}$, dan Na-Benzoat) 
Pada Gambar 11 menunjukkan bahwa kenaikan titik didih pada campuran larutan $(\mathrm{NaCl}$, $\mathrm{KCl}$, dan Na-Benzoat) berbanding lurus dengan berat jenisnya, baik pada campuran 1:1:1 maupun pada campuran 1:1:1,3. Seperti yang sudah dijelaskan sebelumnya, berat jenis terhadap sifat koligatif (tekanan osmosis, penurunan titik beku, dan kenaikan titik didih) berbanding lurus karena dipengaruhi oleh banyaknya zat terlarut. Makin banyak zat terlarut yang terdapat dalam suatu larutan maka akan makin tinggi juga berat jenisnya. Begitupun juga makin tinggi berat jenisnya maka akan makin tinggi juga nilai sifat koligatifnya pada tekanan osmosis, penurunan titik beku, dan kenaikan titih didih.

Pada rumus yang sudah didapat, tekanan osmosis berbanding lurus dengan penurunan titik beku dan kenaikan titik didih. Artinya penentuan sifat koligatif berdasarkan berat jenisnya dapat berlaku untuk larutan yang sudah diketahui konsentrasi maupun zat terlarutnya, baik pada larutan tunggal ataupun pada campuran. Berdasarkan persamaan yang sudah didapat, penentuan sifat koligatif dapat dilakukan dengan mengukur salah satu sifat koligatifnya (tekanan osmosis, penurunan titik beku, dan kenaikan titik didih) dan secara tidak langsung melalui perhitungan matematis dapat diperoleh hasil yang lainnya. Akan tetapi penentuan sifat koligatif berdasarkan berat jenis ini tidak dapat berlaku untuk air zamzam dengan proses pemanasan. Karena berdasarkan data yang ada, hasil pengukuran berat jenis pada air zamzam dengan proses pemanasan tidak menunjukkan keteraturan, yang disebabkan oleh terdapatnya zat yang mudah terdekomposisi seperti ion karbonat dan bikarbonat pada air zamzam. Maka dari itu untuk penentuan penurunan titik beku dan kenaikan titik didih pada air zamzam tidak dapat dihitung menggunakan rumus, karena berdasarkan data yang ada, air zamzam tidak berlaku pada sifat koligatif.

\section{SIMPULAN}

Dari hasil penelitian ini dapat ditarik kesimpulan sebagai berikut:
1. Penentuan sifat koligatif dari larutan garam tunggal maupun campuran larutan garam seperti $\mathrm{NaCl}, \mathrm{KCl}$, dan Na-Benzoat dapat dilakukan dengan pengukuran berat jenis.

2. Penentuan sifat koligatif pada larutan yang tidak diketahui konsentrasi dan zat terlarutnya seperti air zamzam pada metode pemanasan, tidak dapat dilakukan dengan pengukuran berat jenis. Hal ini dikarenakan larutan tersebut mengandung ion-ion yang dapat terdekomposisi.

\section{UCAPAN TERIMA KASIH}

Penulis mengucapkan terima kasih kepada Laboratorium Instrumen Kimia FST UIN SGD Bandung atas penyediaan fasilitas untuk melaksanakan penelitian dan Pihak PT. Sanbe Farma yang telah mengizinkan untuk melakukan analisis instrumen..

\section{REFERENSI}

[1] Raymond Chang, Chemistry Ninth Edition. New York: McGraw-Hill, 2007.

[2] Nurdiana Pemi, "Studi Pendahuluan Fenomena Sifat Koligatif pada Larutan $\mathrm{NaCl}$ dan Air Laut ditinjau dari Penurunan Titik Beku," UIN Sunan Gunung Djati Bandung, Bandung, Skripsi 2015.

[3] M Fauziah, "Studi Pendahuluan Sifat Koligatif Berdasarkan Eksperimen dari Larutan $\mathrm{KCl}$ dan Air Kelapa ditinjau dari Penurunan Titik Beku," UIN Sunan Gunung Djati Bandung, Bandung, Skripsi 2015.

[4] Z S Multazam, "Studi Beberapa Sifat Fisika dan Kandungan Kimia Air Zamzam Serta Perbandingannya dengan Air Minum dalam Kemasan," UIN Sunan Gunung Djati Bandung, Bandung, Skripsi 2016.

[5] H Ghrefat, "Classification and Evaluation of Commercial Bottled Drinking Water in Saudi Arabia," Research Journal of Environmental and Earth Sciences, vol. 4, no. 5, p. 213, 2013. 